Pacific Northwest National Laboratory

Operated by Battelle for the

U.S. Department of Energy

\title{
Texas State Building Energy Code: Analysis of Potential Benefits and Costs of Commercial Lighting Requirements
}

\author{
E.E. Richman \\ D.B. Belzer \\ D.W. Winiarski
}

September 2005

Completed for the Building Standards and Guidelines Program, U.S. Department of Energy under Contract DEAC06-76RLO 1830 


\title{
Texas State Building Energy Code: Analysis of Potential Benefits and Costs of Commercial Lighting Requirements
}

\author{
E.E. Richman \\ D.B. Belzer \\ D.W. Winiarski
}

September 2005

Completed for the Building Standards and Guidelines Program, U.S. Department of Energy under Contract DE-AC06-76RLO 1830 


\title{
DISCLAIMER
}

This report was prepared as an account of work sponsored by an agency of the United States Government. Neither the United States Government nor any agency thereof, nor Battelle Memorial Institute, nor any of their employees, makes any warranty, express or implied, or assumes any legal liability or responsibility for the accuracy, completeness, or usefulness of any information, apparatus, product, or process disclosed, or represents that its use would not infringe privately owned rights. Reference herein to any specific commercial product, process, or service by trade name, trademark, manufacturer, or otherwise does not necessarily constitute or imply its endorsement, recommendation, or favoring by the United States Government or any agency thereof, or Battelle Memorial Institute. The views and opinions of authors expressed herein do not necessarily state or reflect those of the United States Government or any agency thereof.

\author{
PACIFIC NORTHWEST NATIONAL LABORATORY \\ operated by \\ BATTELLE \\ for the \\ UNITED STATES DEPARTMENT OF ENERGY \\ under Contract DE-AC06-76RL01830
}

\author{
Printed in the United States of America \\ Available to DOE and DOE contractors from the \\ Office of Scientific and Technical Information, \\ P.O. Box 62, Oak Ridge, TN 37831-0062; \\ ph: (865) 576-8401 \\ fax: (865) 576-5728 \\ email: reports@adonis.osti.gov \\ Available to the public from the National Technical Information Service, \\ U.S. Department of Commerce, 5285 Port Royal Rd., Springfield, VA 22161 \\ ph: (800) 553-6847 \\ fax: (703) 605-6900 \\ email: orders@ntis.fedworld.gov \\ online ordering: http://www.ntis.gov/ordering.htm
}

This document was printed on recycled paper.

$(8 / 00)$ 


\section{Summary}

The State Energy Conservation Office of Texas has asked the U.S. Department of Energy to analyze the potential energy effect and cost-effectiveness of the commercial lighting requirements in the 2003 International Energy Conservation Code (IECC) as they consider adoption of this energy code. The new provisions of interest in the lighting section of IECC 2003 include new lighting power density (LPD) allowances and requirements for automatic lighting shutoff controls. The potential effect of the new LPD values is analyzed as a comparison with previous values in the nationally available IECC codes and the most recent allowances in the ASHRAE/IESNA 90.1 energy standard. The analysis is based on a set of lighting models developed as part of the ASHRAE/IES code development process, which is the basis for IECC 2003 LPD values. The use of the models allows for an effective comparison of values for various building types that are of interest in the state of Texas. Potential effects from control requirements are discussed, and available case study analysis results are provided, but no comprehensive numerical evaluation related to lighting controls is provided in this limited analysis effort.

The LPD analysis concludes that the change in weighted average power density requirements across all building types is estimated to be a decrease of 0.44 watts per square foot. The corresponding installation costs to meet these new requirements are estimated to decrease by $\$ 0.79$ per square foot as a result of reduced fixture requirements. The new controls requirements are found to be cost-effective on a wholebuilding weighted basis with a payback period under 5 years.

The weighted average reduction in electricity consumption per square foot for lighting is estimated to be about $1.6 \mathrm{kWh}$. Reduced cooling consumption is estimated to about $0.3 \mathrm{kWh}$ per square foot. New nonresidential construction in Texas covered by the code change is projected to increase from just over 200 million square feet per year to over 300 million square feet by 2030. By 2010, annual statewide electricity savings are projected to exceed 2 billion $\mathrm{kWh}$, with reductions in total cost to commercial customers of over $\$ 300$ million. Over the entire period from 2006 through 2030, the net present value of the energy and lighting fixture cost savings is estimated to be greater than $\$ 6$ billion. 


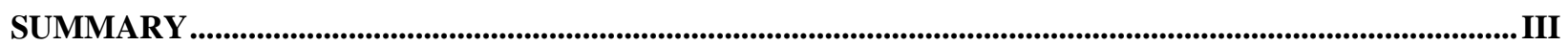

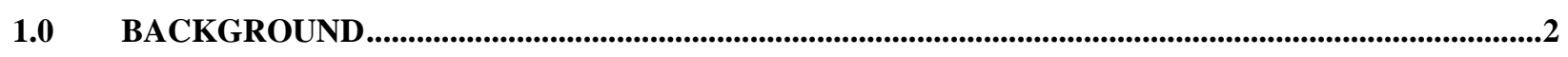

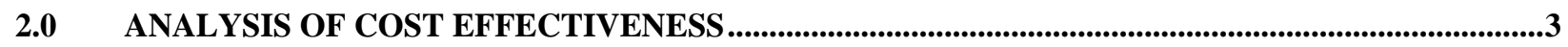

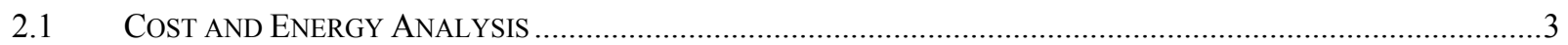

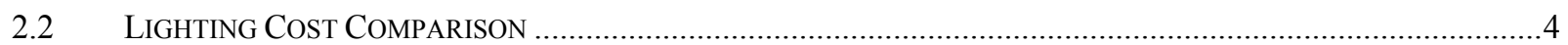

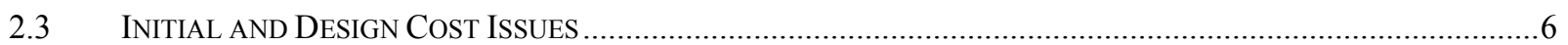

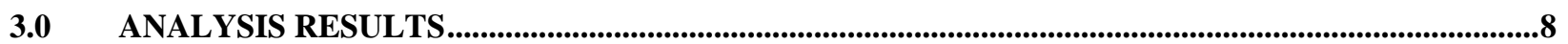

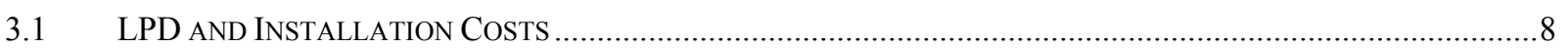

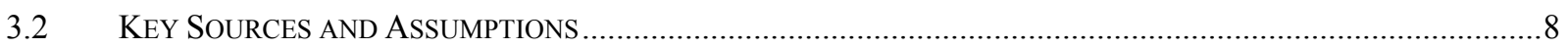

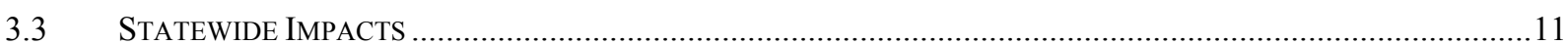

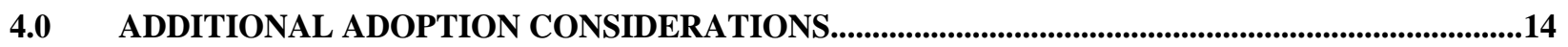

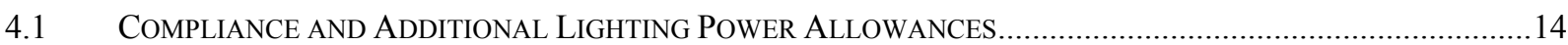

4.2 2003 IECC AMENDMENT FOR SECTION 805.6 ON EXTERIOR EFFICACY …...................................................14

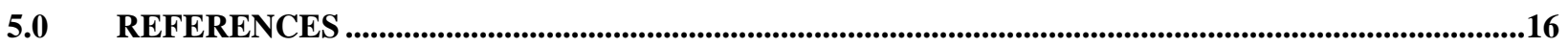

APPENDIX: LIGHTING IMPACTS ON SPACE CONDITIONING................................................................17

\section{Tables}

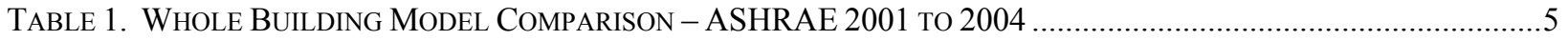

TABLE 2. ENERGY SAVINGS PER SQUARE FoOT BY BUILDING TYPE AND END USE ................................................10

TABle 3. Statewide ANnual Energy and Cost ImpaCts from Lighting Code ChangeS ................................12 


\section{Acronyms and Abbreviations}

$\begin{array}{ll}\text { ASHRAE } & \text { American Society of Heating, Refrigerating and Air-Conditioning Engineers } \\ \text { CBECS } & \text { Commercial Buildings Energy Consumption Survey } \\ \text { DOE } & \text { U.S. Department of Energy } \\ \text { EIA } & \text { Energy Information Administration } \\ \text { HID } & \text { High Intensity Discharge } \\ \text { HPS } & \text { High Pressure Sodium } \\ \text { IECC } & \text { International Energy Conservation Code } \\ \text { IES } & \text { Illuminating Engineering Society } \\ \text { LBNL } & \text { Lawrence Berkeley National Laboratory } \\ \text { LPD } & \text { Lighting Power Densities } \\ \text { LPS } & \text { Low Pressure Sodium } \\ \text { MH } & \text { Metal Halide } \\ \text { MV } & \text { Mercury Vapor } \\ \text { NEMS } & \text { National Energy Modeling System } \\ \text { PNNL } & \text { Pacific Northwest National Laboratory }\end{array}$




\subsection{Background}

Commercial building energy codes are intended to set minimum standards for design and construction while ensuring occupant comfort. These codes eliminate building design practices that lead to unnecessarily high building energy use and associated costs. In 2001, the State of Texas adopted the International Energy Conservation Codes (IECC 2001) as its statewide commercial building energy code standard. The state is now contemplating updating these codes to the 2003 version of the IECC. This change would primarily impact the lighting requirements for commercial buildings; thus, this report examines the potential impacts of updating current lighting requirements in Texas to the more recent version of IECC 2003.

The adoption of the 2003 IECC would include the adoption of a revised subset of the new lower Lighting Power Density (LPD) allowances that are a part of the ANSI/ASHRAE/IESNA 90.1-2004 Energy Standard for Buildings except Low-Rise Residential Buildings (hereafter referred to 90.1-2004 or ASHRAE 90.12004). There are sections of the 2003 IECC, however, that refer to the previously published edition of the ASHRAE standard, ASHRAE 90.1-2001, which does not include these newly revised LPD values. To reduce confusion that may occur due to the outdated references, one possible remedy may be to amend Texas State Code such that the lighting requirements refer to the new values (addenda $g$ and ag to 90.12001 which modify LPD tables 9.3.1.1 and 9.3.1.2). This could also be accomplished by simply changing the ASHRAE 90.1 reference in the IECC to the 2004 version of ASHRAE 90.1 such that only the new LPD values could be used for compliance. Questions may arise, however, regarding the impact these newer lighting requirements would have on commercial construction in the state of Texas. To address this issue, an analysis of the effectiveness of the adoption of the new LPD values for the state of Texas is provided by directly comparing these LPD values with existing LPD levels represented in the current IECC 2001 code. Because the complete ASHRAE/IESNA 90.1-2001 (which is the basis for IECC 2001) and ASHRAE/IESNA 90.1-2004 (basis for IECC 2003) sets of LPD values are supported by detailed models, they provide the most convenient means to analyze the impacts from adopting the more recent code.

The analysis in this report is a code-to-code comparison, where it assumes that buildings just meet the LPD levels in each code. It is understood that buildings are not built precisely to code levels, and that actual percentage of compliance above and below codes will vary among individual buildings and building types. However, without specific knowledge of current construction practices for newly constructed and renovated buildings, it is not possible to provide a rigorous estimate of the likely actual effects of code adoption. It is possible, however, to compare code levels and determine the potential effect of changes from one code requirement level to another. This is the comparison and effectiveness assessment provided by this analysis. 


\subsection{Analysis of Cost Effectiveness}

This analysis is based on a set of models that were originally used to derive the LPD values in the the most recent version of the ASHRAE standard and current IECC. These basic models are mathematical representations of typical "good quality" lighting designs for approximately 120 different space types commonly found in buildings. Space types define areas of the building with a single function such as a lobby, stairway, restroom, etc. The output of these models is a LPD for each space type, which forms the space type LPD requirements in the IECC and ASHRAE standards. These space-type LPDs are applied to a dataset of 246 recently constructed buildings from across the nation in which the proportions of total floor space has been estimated for the various space types. Whole building LPDs are based on the weighting the individual space-type LPDs by the square footage shares of those space type in this sample of real buildings. The dataset contains multiple buildings for each building type (e.g., office, retail, school, etc.) and the LPD results for these are averaged to represent a typical building type LPD requirement.

\subsection{Cost and Energy Analysis}

These ASHRAE 90.1 models were modified for the current analysis to generate lighting equipment cost estimates for each space type, consistent with the LPD for that space type. The original models provide information on generic lighting technology types and the relative quantities of each that represent the lighted space type. This lighting technology information was used to develop typical costs for each space type for both the ASHRAE 2001 (basis for IECC 2001) and the ASHRAE 2004 (basis for IECC 2003) sets of models.

The development of appropriate cost data for equipment such as lighting is difficult because of the great variability in features. Lighting products that provide comparable illumination levels at similar efficiencies and distribution characteristics can come in a wide variety of styles and configurations, with greatly varying costs. This situation is unlike some other major building energy components such as mechanical systems and envelope materials, where the cost is generally driven by the equipment efficiency or quantity of material. Lighting, rather, includes a very large decorative or visible art component that impacts cost.

To make reasonable comparison between different LPD levels, the analysis chose basic types of fixtures (minus any decorative or art components) for which nationally consistent cost data could be obtained. The LPD models are already based on basic equipment representing good quality but low decorative components. The source for consistent cost data is primarily either the R.S. Means building cost data reference (RS Means 2005) or the Grainger Supply catalog (Grainger \#395 2004-2005). The R.S. Means data is a well recognized source for building construction cost estimating that provides material, labor, and overhead estimates for a variety of lighting products. R.S. Means also tracks location-specific cost indexes for adjusting the basic cost data. The Grainger Supply catalog represents a major retail source of lighting equipment with nationally consistent prices. The Grainger catalog provides additional detail on specific equipment that is not available in the Means data source and is used to supplement the base Means estimates. 
Each of the LPD models is populated with lighting fixture data from one to three different fixture types from a list of 34 defined fixture types. Fixture costs for each of the 34 types were developed from the two cost sources, which are in turn applied to the space type models. This development included deriving a base fixture cost and associated installation labor and subsequently adjusting those costs to better reflect actual buildings costs in Texas. The Means and Grainger sources were used, where applicable, to derive an installed (national average) cost for each fixture. The Means cost indexes for Texas cities were used to derive a weighted state index for Texas using city population data from the U.S. Census Bureau. The resulting costs used for this analysis include material plus labor adjusted by the weighted Texas state index. As a final step, a constant $20 \%$ markup was applied to all costs to account for overhead and profits. The Grainger catalog was used to assign a typical wattage to each fixture type. These wattages were used to apply the appropriate cost for each of the one to three fixture types in the model based on the model's use of them based on wattage and efficacy.

The individual space type model formulas were modified to derive costs (instead of LPD) based on the developed fixture costs and index. While the general framework behind the ASHRAE 2001 and 2004 models are the same, some of the characteristics of the models are different including different fixture choices and, of course, the quantities of fixtures needed to provide the lighting represented by the LPD value. These differences drive the change in cost for each space type between the 2001 to 2004 standards. For consistency of the analysis, the efficiencies of the fixtures and the set of buildings used to develop the whole building values were based (for both code levels) on the most recent data used in the development of the 2004 ASHRAE Standard. This provides a consistent basis because new buildings designed to meet either code would apply the same equipment with current efficiencies.

\subsection{Lighting Cost Comparison}

The models provide detailed data that can be used to compare individual space type characteristics between the two code levels. However, the comparisons for specific space types can not be readily aggregated to show the overall statewide effect of adopting the most recent code. Therefore, the whole building cost estimates derived in the analysis are used for comparisons. For each building type, the models are used to derive both the difference in fixture cost and difference in energy (power density) between the application of IECC 2001 and 2003 LPD levels. The cost difference is the difference between the costs per square foot that would be required to meet the whole building lighting requirements for the ASHRAE 2001 models versus the costs per square foot to meet the LPD requirements of the ASHRAE 2004 models, which represent the more stringent limits. The energy difference is the wattage (power density) difference per square foot. These values for the 32 building types are shown in Table 1. 
Table 1. Whole Building Model Comparison - ASHRAE 2001 to 2004

\begin{tabular}{|c|c|c|c|c|}
\hline Building Type & $\begin{array}{l}\text { 90.1-2001 } \\
\text { LPD }\end{array}$ & $\begin{array}{c}90.1-2004 \\
\text { LPD }\end{array}$ & $\begin{array}{c}\text { LPD } \\
\text { "Change" in } \\
\text { W/sf }\end{array}$ & $\begin{array}{c}\text { Cost } \\
\text { "Change" } \\
\text { in } \$ / s f\end{array}$ \\
\hline Automotive Repair & 1.5 & 0.9 & $(0.6)$ & $(0.97)$ \\
\hline Convention Center & 1.4 & 1.2 & $(0.2)$ & $(0.34)$ \\
\hline Courthouse & 1.4 & 1.2 & $(0.2)$ & (0.62) \\
\hline Dining-Bar Lounge/Leisure & 1.5 & 1.3 & $(0.2)$ & $(0.22)$ \\
\hline Dining-Café/Fast Food & 1.8 & 1.4 & $(0.4)$ & 0.09 \\
\hline Dining-Family & 1.9 & 1.6 & $(0.3)$ & 0.32 \\
\hline Dormitory & 1.5 & 1.0 & $(0.5)$ & $(2.53)$ \\
\hline Exercise Center & 1.4 & 1.0 & $(0.4)$ & (0.09) \\
\hline Fire Station & 1.3 & 0.8 & $(0.5)$ & $(0.52)$ \\
\hline Gymnasium & 1.7 & 1.1 & $(0.6)$ & $(0.07)$ \\
\hline Healthcare-Hospital & 1.6 & 1.2 & $(0.4)$ & $(0.92)$ \\
\hline Hotel & 1.7 & 1.0 & $(0.7)$ & (1.92) \\
\hline Library & 1.5 & 1.3 & $(0.2)$ & $(0.25)$ \\
\hline Manufacturing & 2.2 & 1.3 & $(0.9)$ & (0.98) \\
\hline Motel & 2.0 & 1.0 & $(1.0)$ & $(2.32)$ \\
\hline Multi-Family & 1.0 & 0.7 & $(0.3)$ & (0.33) \\
\hline Museum & 1.6 & 1.1 & $(0.5)$ & $(0.65)$ \\
\hline Office & 1.3 & 1.0 & $(0.3)$ & $(0.77)$ \\
\hline Parking Garage & 0.3 & 0.3 & 0.0 & 0.04 \\
\hline Penitentiary & 1.2 & 1.0 & $(0.2)$ & $(0.54)$ \\
\hline Police Station & 1.3 & 1.0 & $(0.3)$ & $(0.57)$ \\
\hline Post Office & 1.6 & 1.1 & $(0.5)$ & (1.12) \\
\hline Religious & 2.2 & 1.3 & $(0.9)$ & (1.13) \\
\hline Retail & 1.9 & 1.5 & $(0.4)$ & (1.51) \\
\hline School-College & 1.5 & 1.2 & $(0.3)$ & $(0.26)$ \\
\hline Sports Arena & 1.5 & 1.1 & $(0.4)$ & $(0.90)$ \\
\hline Theater-Performing Arts & 1.5 & 1.6 & 0.1 & 0.01 \\
\hline Theatre-Motion Picture & 1.6 & 1.2 & $(0.4)$ & $(0.40)$ \\
\hline Town Hall & 1.4 & 1.1 & $(0.3)$ & $(0.66)$ \\
\hline Transportation & 1.2 & 1.0 & $(0.2)$ & $(0.10)$ \\
\hline Warehouse & 1.2 & 0.8 & $(0.4)$ & $(0.10)$ \\
\hline Workshop & 1.7 & 1.4 & $(0.3)$ & $(0.16)$ \\
\hline
\end{tabular}

It is clear from the Table 1 that the majority of the building types (28) exhibit both a decrease in cost and a decrease in energy between the two code levels. For these cases, there is a clear advantage in both cost and energy to moving to the new code level. Both energy and cost decreases are a direct result of the predominant reduction in LPD allowances derived for the 90.1-2004 energy standard as compared to the values in the 1999 version of that standard. The reductions were the result of a variety of changes in lighting technology, industry accepted illuminance recommendations and design practices. These changes reflect the fact that the earlier version of the standard (1999), while based on available information of the time, represented higher illuminance recommendations, and lower efficiency equipment than is currently applied in typical lighting design. While some may perceive this change between the two standards as a simple reduction of LPD for energy savings, it in fact is just an 
acknowledgement of the latest available data and information on current design practice. The remaining four building types exhibit mixed increases and decreases that are also related to changes in design practice and are worth examining individually.

\section{Dining - Cafeteria Fast Food}

The energy savings of 0.40 watts per square foot for this building type will offset the additional equipment cost that results from changes in current design choices of lighting technologies for restaurant applications. This is calculated using an estimated weekly lighting operation time for this building type of 84 hours (EIA 1999, Commercial Building Energy Conservation Survey) and the 2004 average electricity cost of 7.84 cents per kilowatt for commercial customers in Texas. For this building type, the estimated simple payback is less than one-half year.

\section{Dining - Family}

The energy savings of 0.30 watts per square foot for this building type will also offset the additional equipment cost. In this case, the estimated simple payback is 2.6 years.

\section{Parking Garage}

The parking garage building type is the only one that experiences no change in lighting power density for whole building. The whole building values represent aggregations of multiple individual space types and building space characteristics. These combinations of changes in the models can produce a null effect such as this for energy with a small effect in cost (or vice versa). In this case, while there is no energy savings, there is a small increase in cost resulting from small changes in technology choices.

\section{Performing Arts Theatre}

In this case both the cost and energy are expected to increase with a change in code levels. The cost change is very small at $\$ 0.01$ per square foot with a moderate rise in energy use at 0.1 watt per square foot based on changes in current design practice and choice of lighting technologies.

To evaluate overall impact of the lighting code change in Texas, it is important to aggregate the effects across all of the various building types. In the absence of state-specific data for Texas, a national representation of building square footage by building type (EIA 1999) was used to weight the effects of the code change across all building types . ${ }^{1}$ The results of this calculation shows a weighted average decrease in lighting fixture cost of $\$ 0.79$ per square foot and a decrease in LPD of 0.44 watts per square foot.

\subsection{Initial and Design Cost Issues}

As shown in this analysis, the initial cost of lighting installations that meet the new LPD values are going to be on average lower than an installation meeting the current 2001 IECC. The overall cost reduction in the number of fixtures will also have additional cost savings over the life of the installation because of

\footnotetext{
${ }^{1}$ The distribution was based upon new floor space constructed between 1990 and 1999. Some of the building types covered by the code (as shown in Table 1) are not included in the CBECS (parking garages, common space in high-rise multi-family, and manufacturing). Separate estimates of the amount of new floor space in these building types built during the 1990-1999 period were developed before the weights were calculated.
} 
reduced need for replacement lamps and ballasts. However, several issues are occasionally raised regarding the practical application of these new requirements.

The first issue is that additional design costs may be incurred to develop lighting designs that will meet the new required LPD limits. Because of the variability in how lighting design is accomplished there are several possible scenarios, listed below in order of increasing cost:

- SCENARIO 1: "Just part of the job - Lighting Designer" - Under this scenario, the lighting is typically designed by a separate firm with an in-house design department, or supplier and any potential additional effort to meet the code limits is a normal part of the design process. Under this scenario, a change in lighting requirements would results in NO ADDITIONAL COSTS.

- SCENARIO 2: "Design change charge - Lighting Designer" - Under this scenario, the lighting is typically designed by a separate firm with an in-house design department, or supplier and any additional effort to meet the new code limits is charged as an adder to the normal design cost. Under this scenario there would be SOME ADDITIONAL COST; however, these costs would likely apply only to first few design jobs after which it becomes common design practice

- SCENARIO 3: "New design charge" - Under this scenario, lighting has been based on previous designs and a change in the lighting requirements would require that a designer be contracted to provide a new code compliance standard design for future use. Under this scenario there would be SIGNIFICANT COSTS for initial design changes.

The third scenario is the most expensive, for which a total lighting redesign is required to meet the new code. Actual lighting design costs are generally project specific and based on the lighting needs and desires expressed by the building owners. However, typical cost of completed full lighting designs for various building types are in the range of $\$ 0.10$ to $\$ 0.75$ per square foot ${ }^{2}$. This cost can be compared to the $\$ 0.79$ per square foot weighted average decrease in equipment cost determined in this analysis for compliance with the new LPDs. Even at worst case, the initial equipment savings overshadow any design costs.

A second issue is the possibility that in some low ceiling applications (e,g,.. some basement areas or remodeled spaces to accommodate ductwork and other systems equipment) initial costs could actually rise due to redesigns to meet the new LPDs. In low-ceiling applications it is often more difficult to achieve uniform light levels (a good design practice) across the work surface if fixtures are placed too far apart. Some high illumination designs make use of wider spacing to help eliminate potential dark spots between fixtures. With designs to meet the new lower LPD limits, designs and equipment choices must be made to ensure reasonable uniformity of lighting within the space. This can be accomplished with fewer fixtures, but such fixtures must have better lighting distribution characteristics. However, an easier method of complying with the new code initially might involve simply installing more fixtures of lower wattage to meet the LPD limits; this strategy would also achieve more uniform lighting. Until greater experience is gained in optimizing designs to meet the new codes in these applications, there may be a period during which total fixture costs might increase, offsetting some of energy cost savings.

\footnotetext{
${ }^{2}$ Personal correspondence with lighting designers.
} 


\subsection{Analysis Results}

In general the results of this analysis appear to suggest that overall, the weighted average lighting power density across all building types will decrease significantly with the revised 2003 IECC lighting requirements. In addition, the impact of lighting costs in the construction of new commercial buildings would also decrease rather significantly, as fewer fixtures would be required to meet the newer standards.

The reduced power density requirements under the IECC 2003 yield lower annual lighting energy use per square foot, depending upon the average annual operating hours in each building type. Energy consumption is also influenced by the interaction between lighting and space conditioning. The reduced internal heat gains from the lower LPD will translate into lower cooling requirements, but somewhat higher heating requirements. In a southern climate such as Texas, the impact on cooling is expected to be greater than that on heating.

\subsection{LPD and Installation Costs}

Specific LPD analysis findings include the following;

- 31 of the 32 building types analyzed show a decrease in allowed lighting power density with adoption of the new code. The Performing Arts Theatre building type increases by 0.1 watt per square foot allowed (1.5 to 1.6) and Parking Garage shows no change in energy.

- 28 of the 32 building types show estimated decreases in lighting installation cost in complying with the new IECC 2003 code LPD levels. This is primarily caused by the new models reflecting the current light level recommendations and applying current equipment efficiencies and design practices that allow less equipment to be able to provide the necessary lighting. Cafeteria/Fast Food Dining, Family Dining, Parking Garage, and Performing Arts Theatre building types experience small to moderate increases in equipment costs.

- The weighted average lighting power density change across all building types is an estimated decrease of 0.44 watts per square foot in lighting power density across the state based on a nationwide mix of new buildings observed during the 1990s.

- The weighted average effect of the cost change across all building types is an estimated decrease in lighting installation costs of $\$ 0.79$ per square foot across the state based on a nationwide mix of new buildings observed during the 1990s.

\subsection{Key Sources and Assumptions}

With regard to information as to the typical operating hours for lighting in different types of commercial buildings three recent sources of data were considered:

- $\quad$ "US Lighting Market Characterization Vol I: National Lighting Inventory and Energy Consumption Estimate", Navigant, Xenergy, for EERE, September 2002 (Navigant Consulting 2002). Commercial (hours) data from XenCap mixed early to mid-90s data and CBECS 1999. 
- Energy Information Administration (EIA) 1999 Commercial Building Energy Consumption Survey

- Energy Information Administration, Office of Energy Markets and End Use, Form EIA-871A, "Building Questionnaire" of the 1986 Nonresidential Buildings Energy Consumption Survey. [from the report: Energy Consumption Series Lighting in Commercial Buildings March 1992, Energy Information Administration.]

Of these sources, the first was considered the most complete and accurately derived and was used in this analysis. These values were developed specifically as part of a well documented commercial lighting study and made use of data from more than one collection source. ${ }^{3}$

The estimated changes in heating and cooling consumption were based upon a set of interaction coefficients, defined as the annual change in cooling (or heating) consumption per annual change in electricity consumption (in $\mathrm{kWh}$ ). ${ }^{4}$ These coefficients were based upon a set of simulations for a small set of building types in Texas, a previous simulation study conducted by Lawrence Berkeley National Laboratory, and PNNL analyst judgment. Details of the development of these coefficients are presented in the Appendix.

Table 2 shows the results of combining these sets of information (LPD reductions, operating hours, and interaction coefficients), expressed in terms of annual energy savings per square foot (sf) by building type. Retail buildings are estimate to account for the largest share of projected new floor space and provide a convenient example. The building weight of 0.1909 is based upon the composition of building construction during the 1990s (and published in the 1999 CBECS). With an average of 78 operating hours per week, the reduced LPD in the 2003 IECC yields annual savings of $1.63 \mathrm{kWh}$ per square foot of retail floor space. The resulting reduction in cooling requirements is estimated to be $0.46 \mathrm{kWh}$ per square foot, based upon the interaction coefficient of 0.28 as shown Table A. 2 in the Appendix.

Heating requirements, however, increase slightly. From the 1999 CBECS, approximately one-half of the new (1990-1999) commercial floor space in the South census region is heated by electricity and one-half by natural gas. Without going to the rigor of developing specific splits by building type, the analysis assigns $50 \%$ of the floor space for each building type to both electricity and natural gas. The interaction coefficients for heating as developed in the Appendix relate to gas heating equipment with an assumed

\footnotetext{
${ }^{3}$ The impact on energy use from the operating hours of lighting in a building can be affected by the diversity of the users of the lighting (i.e. lights get turned on and off during the day) that can reduce actual energy use. At the same time typical audits of lighting data such as those used in this study are not always able to account for all "after hours" lighting that would increase energy use. This study did not specifically apply a diversity factor or specifically address after hours lighting. However, a primary audit data source in the 2002 Navigant study (XenCAP) did estimate lighting operating hours based on the different lighting types and spaces within the building. This practice reduces the potential error associated with omitting an explicit diversity factor and should provide a more accurate means of estimating energy used for lighting.

${ }^{4}$ The interaction coefficient for cooling also includes any changes in the fan energy (electricity) associated with reduction in the internal heat gain associated with the lower LPDs. The change in fan energy use is a net value - the decrease in fan energy use associated with cooling is offset to some degree by an increase during heating periods.
} 
efficiency of $80 \%$. Heating from electric equipment may be from electric resistance coils or heat pumps, both more efficient on a site energy basis than natural gas. The interaction coefficients for electric heating shown in column five of Table 2 were based upon an assumption of an weighted average seasonal COP of 1.5 for electric heating equipment (i.e., one-half of space using electric resistance with efficiency near 1.0 and the other half using heat pumps with a seasonal efficiency of 2.0). The natural gas interaction coefficients in the last column of the table have been converted to a Btu basis $(1 \mathrm{kWh}=3.412$ $\mathrm{kBtu}$ ). Both columns reflect the adjustment for the 50-50 split between electric and gas heated floor space as discussed above, and so are actually equal to 0.5 times the interaction coefficient assigned for each building type and fuel.

The next section of the report discusses the aggregation of the energy savings estimates in Table 2 to a statewide level. For that purpose, it is assumed that the composition of new nonresidential floor space, as estimated in $2^{\text {nd }}$ column of Table 2 , does not change over time. This assumption allows the use of an overall average of energy savings per square foot that reflects all building types. These weighted averages are shown in the last row of Table 2.

Table 2. Energy Savings per Square Foot by Building Type and End Use

\begin{tabular}{|c|c|c|c|c|c|c|c|}
\hline Building Type & $\begin{array}{l}\text { Bldg Weight } \\
\text { (fraction) }\end{array}$ & $\begin{array}{c}\text { Weekly } \\
\text { Hours } \\
\text { (number) }\end{array}$ & $\begin{array}{l}\text { Lighting } \\
\text { (kWh/sf) }\end{array}$ & $\begin{array}{r}\text { Cooling } \\
\text { (kWh/sf) }\end{array}$ & $\begin{array}{l}\text { Heating } \\
\text { (electric) } \\
\text { (kWh/sf) }\end{array}$ & $\begin{array}{c}\text { Total } \\
\text { Electric } \\
\text { (kWh/sf) }\end{array}$ & $\begin{array}{l}\text { Heating } \\
\text { (nat. gas) } \\
\text { (kBtu/sf) }\end{array}$ \\
\hline Automotive Repair & 0.0054 & 65.8 & 2.05 & 0.04 & $(0.01)$ & 2.08 & $(0.07)$ \\
\hline Convention Center & 0.0098 & 51.1 & 0.53 & 0.13 & $(0.01)$ & 0.65 & $(0.06)$ \\
\hline Courthouse & 0.0030 & 67.2 & 0.70 & 0.17 & (0.01) & 0.86 & $(0.08)$ \\
\hline Dining-Bar Lounge/Leisur & 0.0081 & 88.2 & 0.92 & 0.23 & $(0.02)$ & 1.12 & $(0.16)$ \\
\hline Dining-Café/Fast Food & 0.0081 & 88.2 & 1.83 & 0.46 & $(0.05)$ & 2.24 & $(0.31)$ \\
\hline Dining-Family & 0.0081 & 88.2 & 1.38 & 0.34 & $(0.04)$ & 1.68 & $(0.23)$ \\
\hline Dormitory & 0.0190 & 70.7 & 1.84 & 0.37 & $(0.10)$ & 2.11 & $(0.63)$ \\
\hline Exercise Center & 0.0054 & 65.8 & 1.37 & 0.27 & $(0.04)$ & 1.61 & $(0.23)$ \\
\hline Fire Station & 0.0030 & 67.2 & 1.75 & 0.35 & $(0.02)$ & 2.07 & (0.15) \\
\hline Gymnasium & 0.0054 & 65.8 & 2.05 & 0.41 & $(0.05)$ & 2.41 & $(0.35)$ \\
\hline Healthcare-Hospital & 0.0377 & 112.0 & 2.33 & 0.70 & $(0.03)$ & 3.00 & $(0.20)$ \\
\hline Hotel & 0.0190 & 70.7 & 2.57 & 0.64 & $(0.10)$ & 3.11 & $(0.66)$ \\
\hline Library & 0.0098 & 51.1 & 0.53 & 0.13 & $(0.01)$ & 0.65 & $(0.06)$ \\
\hline Manufacturing & 0.1105 & 67.9 & 3.18 & 0.32 & $(0.04)$ & 3.45 & $(0.27)$ \\
\hline Motel & 0.0190 & 70.7 & 3.68 & 0.74 & $(0.20)$ & 4.22 & (1.25) \\
\hline Multi-Family & 0.0147 & 70.7 & 1.10 & 0.22 & $(0.06)$ & 1.26 & $(0.38)$ \\
\hline Museum & 0.0098 & 51.1 & 1.33 & 0.40 & $(0.02)$ & 1.70 & $(0.16)$ \\
\hline Office & 0.1458 & 72.1 & 1.12 & 0.31 & $(0.02)$ & 1.42 & $(0.13)$ \\
\hline Parking Garage & 0.0239 & 67.9 & 0.00 & 0.00 & 0.00 & 0.00 & 0.00 \\
\hline Penitentiary & 0.0030 & 67.2 & 0.70 & 0.17 & $(0.02)$ & 0.85 & $(0.12)$ \\
\hline Police Station & 0.0030 & 67.2 & 1.05 & 0.26 & $(0.02)$ & 1.29 & $(0.13)$ \\
\hline Post Office & 0.0030 & 67.2 & 1.75 & 0.44 & $(0.03)$ & 2.15 & $(0.21)$ \\
\hline Religious & 0.0284 & 35.0 & 1.64 & 0.33 & $(0.04)$ & 1.92 & $(0.28)$ \\
\hline Retail & 0.1909 & 78.2 & 1.63 & 0.46 & $(0.02)$ & 2.06 & $(0.14)$ \\
\hline School-College & 0.0987 & 53.2 & 0.83 & 0.21 & $(0.04)$ & 0.99 & $(0.28)$ \\
\hline Sports Arena & 0.0098 & 51.1 & 1.06 & 0.16 & $(0.01)$ & 1.21 & (0.09) \\
\hline Theater-Performing Arts & 0.0098 & 51.1 & $(0.27)$ & $(0.07)$ & 0.00 & $(0.33)$ & 0.03 \\
\hline Theatre-Motion Picture & 0.0098 & 51.1 & 1.06 & 0.27 & $(0.02)$ & 1.31 & $(0.13)$ \\
\hline Town Hall & 0.0030 & 67.2 & 1.05 & 0.26 & $(0.02)$ & 1.29 & $(0.13)$ \\
\hline Transportation & 0.0054 & 65.8 & 0.68 & 0.14 & $(0.02)$ & 0.80 & $(0.12)$ \\
\hline Warehouse & 0.1656 & 67.9 & 1.41 & 0.07 & $(0.01)$ & 1.48 & $(0.05)$ \\
\hline Workshop & 0.0054 & 67.9 & 1.06 & 0.11 & $(0.01)$ & 1.15 & $(0.09)$ \\
\hline All Buildings & 1.0000 & 69.5 & 1.58 & 0.30 & $(0.03)$ & 1.85 & $(0.20)$ \\
\hline
\end{tabular}




\subsection{Statewide Impacts}

Estimates of the statewide impacts of the lighting code changes are developed for a future time horizon extending from 2006 through 2030. These impacts depend upon projections of new and renovated commercial floor space, energy costs, and the estimates of energy savings per square foot shown above.

Projected new additions to nonresidential floor space in Texas are estimated to be over 200 million square feet in 2006, increasing to over 300 million square feet in 2030. This projection is based, in part, upon the Department of Energy's National Energy Modeling System (NEMS) that provides long-term energy forecasts published in the Annual Energy Outlook 2005. The commercial building model in NEMS generates projections of new floor space additions by census division. New nonresidential building construction in Texas is estimated to account for about $75 \%$ of the construction in the West South Central census division. ${ }^{5}$

The projection of new building floor space is augmented by a rough estimate of floor space that is renovated each year. Information on the amount of commercial floor space that is renovated each year is very limited. Based upon a 1989 national survey by the census bureau and a more recent report for California, a conservative estimate is that the ratio of renovated to new floor space, and for which new lighting fixtures would be installed, may be at least $20 \%{ }^{6}$

${ }^{5}$ Two adjustments are made to the initial projections from the NEMS model. The first adjustment reduces the NEMS projection by approximately $24 \%$; this adjustment is made to calibrate the estimates to a national historical floor space model being developed by PNNL. The PNNL model is calibrated to a series of historical national floor space estimates provided in various Commercial Building Energy Consumption Surveys (CBECS), conducted by the Department of Energy's Energy Information Administration. The second adjustment accounts for a difference of the definitional scope of nonresidential buildings. Some nonresidential building types covered the IECC are not included in NEMS (and CBECS): parking garages, common areas in high-rise multifamily buildings, and manufacturing buildings. Over the period 1990-1999, the new floor space in these buildings is estimated to have been about $17 \%$ of the total new national floor space in the commercial buildings covered in the CBECS. Thus, the second adjustment adds an additional $17 \%$ to reflect this floor space.

${ }^{6}$ The first source was from a special survey on nonresidential building improvement made as part of the 1989 CBECS, but published by the Construction Statistics Bureau, U.S. Census Bureau in 1992 (Construction Review, Spring-summer 1992). The second source was an article presented at the 2002 ACEEE Summer Study on Energy Efficiency in Buildings: Donald Dohrmann et al., "Remodeling and Renovation of Nonresidential Buildings in California." This article indicated that renovated floor space represented about $20 \%$ of new floor space in California during the 1970 s, but has increased dramatically since then. On a national basis, and over a long period of time, the $20 \%$ assumption is deemed to represent a conservative value. 
State-level energy prices are derived from data files compiled by the Energy Information Administration. ${ }^{7}$ The average retail price of electricity sold to commercial customers in Texas in 2004 was 7.84 cents $/ \mathrm{kWh}$. For the period December 2003 through December 2004, the average natural gas price for commercial customers in Texas was $\$ 8.17$ per million cubic feet. For purposes of the economic impact assessment, these prices are assumed to remain constant in the future. ${ }^{8}$

Table 3 shows the estimated statewide energy and cost impacts from the proposed lighting amendments. By 2010, over one billion square feet of new floor space will have been built, yielding electricity savings near 2 billion $\mathrm{kWh}$ per year. Including the small offsetting increase in natural gas use for heating, total energy savings in 2010 would be nearly 7 trillion Btu. (The estimated energy savings are on a site basisthey do not include generation and transmission losses by electric utilities.) By 2030, with over 6.5 billion square foot of floor space built to the more stringent lighting requirements, total energy savings in the state would be nearly 40 trillion Btu.

Assuming full compliance with the more stringent lighting requirements, first year cost savings are over $\$ 100$ million. The $\$ 84$ million cost savings in 2006 under the heading of fixture cost savings is net of the estimated cost for additional design work to comply with the new lighting LPD requirements (estimated to be $\$ 0.40$ per square foot). Assuming that these design costs are borne only in the first year of the new code, the savings in the second year and subsequent years exceeds $\$ 173$ million per year.

Energy cost savings are nearly proportional to the cumulative amount of floor space that is designed to meeting the new requirements. In the first year of the new code, the cost savings are over $\$ 30$ million. All of the cost savings stem from reduced electricity costs for the lighting and associated cooling impacts. By 2030, the energy cost savings reach nearly one billion dollars per year.

\section{Table 3. Statewide Annual Energy and Cost Impacts from Lighting Code Changes}

\begin{tabular}{|c|c|c|c|c|c|c|c|c|}
\hline Year & $\begin{array}{l}\text { New and } \\
\text { Renovated } \\
\text { Floor Space } \\
\text { (Million SF) }\end{array}$ & $\begin{array}{c}\text { Cumulative } \\
\text { New+Reno- } \\
\text { vated Floor } \\
\text { Space } \\
\text { (Million SF) }\end{array}$ & $\begin{array}{l}\text { Electricity } \\
\text { Savings } \\
\text { (Mill. kWh) }\end{array}$ & $\begin{array}{l}\text { Natural Gas } \\
\text { Savings } \\
\text { (Trill. Btu) }\end{array}$ & $\begin{array}{l}\text { Total Energy } \\
\text { Savings } \\
\text { (Trill. Btu) }\end{array}$ & $\begin{array}{l}\text { Fixture Cost } \\
\text { Savings } \\
\text { (Mill. 2004\$) }\end{array}$ & $\begin{array}{l}\text { Energy Cost } \\
\text { Savings } \\
\text { (Mill. 2004\$) }\end{array}$ & $\begin{array}{l}\text { Total Cost } \\
\text { Savings } \\
\text { (Mill. 2004\$) }\end{array}$ \\
\hline 2006 & 214 & 214 & 396 & $(0.04)$ & 1.35 & 84 & 31 & 115 \\
\hline 2007 & 218 & 432 & 799 & (0.09) & 2.73 & 173 & 63 & 235 \\
\hline 2008 & 220 & 652 & 1,207 & (0.13) & 4.12 & 175 & 95 & 269 \\
\hline 2009 & 224 & 876 & 1,620 & $(0.17)$ & 5.53 & 178 & 127 & 305 \\
\hline 2010 & 227 & 1,103 & 2,040 & $(0.22)$ & 6.96 & 180 & 160 & 340 \\
\hline 2015 & 248 & 2,299 & 4,252 & $(0.46)$ & 14.51 & 197 & 333 & 530 \\
\hline 2020 & 267 & 3,595 & 6,650 & $(0.71)$ & 22.69 & 212 & 521 & 733 \\
\hline 2025 & 299 & 5,019 & 9,285 & (1.00) & 31.68 & 237 & 728 & 965 \\
\hline 2030 & 335 & 6,621 & 12,248 & (1.31) & 41.79 & 266 & 960 & 1,226 \\
\hline
\end{tabular}

\footnotetext{
${ }^{7}$ Electricity prices from http://www.eia.doe.gov/cneaf/electricity/epm/table5 6 b.html. Natural gas prices taken from http://tonto.eia.doe.gov/dnav/ng/hist/n3020tx3m.htm.

${ }^{8}$ The assumption of constant electricity and fuel prices is in rough agreement with the projections in the 2005 Annual Energy Outlook (AEO) for the West South Central census division. The AEO actually projects a slight decline in both electricity and gas prices for 2025 as compared to current prices.
} 
Net present value provides a single metric by which to value the total cost savings over a period of future years. ${ }^{9}$ Using a discount rate of 7\% and the stream of savings from 2006 through 2030 , the net present value of the proposed lighting amendment in Texas is over $\$ 6$ billion.

\section{Qualifying Note}

It is important to note that while this analysis can do a reasonable job of comparing code levels and their potential for aggregate energy and cost savings, it does not try to ascertain current practice, and, therefore, what may be the actual effects of a more stringent code. Builders have and will continue to design buildings (and lighting) based on client needs and desires, with energy code compliance, at best, a companion consideration. Therefore, it is probable that some (or many) buildings are already designed better than existing codes and may require minimal or no change to meet future codes. More rigorous accounting for these buildings would reduce the estimates of the aggregate energy savings for Texas, but would not affect the overall economic analysis results of adopting the lighting levels from the 2003 IECC. A similar comment can be made about the potential compliance with the new code. It is unrealistic to expect $100 \%$ compliance with the proposed change in energy code, but that consideration as well does not change the underlying cost effectiveness of the change.

\footnotetext{
${ }^{9}$ In general, "Net" Present Value (NPV) represents the difference between the discounted costs and discounted benefits over a series of future periods. In this case, the discounted costs are only the estimated design costs that are assumed to occur in the first year of the new code.
} 


\subsection{Additional Adoption Considerations}

\subsection{Compliance and Additional Lighting Power Allowances}

In addition to the cost effectiveness considerations for new code adoption, other factors may merit consideration. It is clear that in areas where culture and design play prominent role in building architecture (particularly in larger cities), lighting design can be an important part of the area's art and commerce. Lighting designers may be concerned with a new set of requirements that appear to drastically restrict lighting design with much lower LPD levels.

It is also understood by code developers that the prominent art elements in many lighting designs (not found in envelope and mechanical energy concerns) creates potential problems with meeting specific code levels. This is the driver behind the additional lighting power allowances provided in the ASHRAE and IECC codes. Because of the unfamiliarity of codes and application, some interested parties may not have a full understanding of the use of the additional allowances. Therefore, the adoption of more stringent codes such as IECC 2003 or ASHRAE 90.1-2004 could be eased within the lighting design community by emphasis and education placed on these allowances.

\subsection{IECC Amendment for Section 805.6 on Exterior Efficacy}

The increase of required lamp efficacy from 45 lumens per watt $(\mathrm{lm} / \mathrm{W})$ to $60 \mathrm{~lm} / \mathrm{W}$ for lamps greater than $100 \mathrm{~W}$ will have some effect on the practical application of exterior lighting design by eliminating the use of some lamps. However, based on the state of current lamp efficacies, the scope of this effect is expected be limited. The commonly used exterior lighting sources include incandescent, fluorescent, and high intensity discharge (HID).

Incandescent sources over $100 \mathrm{~W}$ are already excluded at the current $45 \mathrm{~lm} / \mathrm{W}$ requirement. Compact fluorescent sources have efficacies generally in the high 50s and therefore could be affected by the proposed $60 \mathrm{~lm} / \mathrm{W}$ requirement. However, they do not commonly exist in wattages approaching $100 \mathrm{~W}$. Linear fluorescent products are also under the $100 \mathrm{~W}$ level. This leaves the class of HID lighting sources--Mercury Vapor (MV), Metal Halide (MH), High Pressure Sodium (HPS), and Low Pressure Sodium (LPS) - as being most likely impacted by the proposed change in the code. LPS sources have efficacies in the range of 150 to $180 \mathrm{~lm} / \mathrm{W}$, well above the new requirement. MH sources have efficacies in the 75 to $125 \mathrm{~lm} / \mathrm{W}$ range and would continue to meet the requirements. The remaining LPS and HPS sources could be affected by the new requirements.

MV sources have efficacies in the 30 to $65 \mathrm{~lm} / \mathrm{W}$ range. There are a few MV lamps in wattages below 100 that would continue to be used but all others would not be allowed under the new requirements. However, MV use is not very common at higher wattages in commercial applications and therefore any effect from the new $60 \mathrm{~lm} / \mathrm{W}$ level would be negligible. HPS sources are a very commonly used source in commercial exterior lighting applications with efficacies ranging between 45 and $150 \mathrm{~lm} / \mathrm{W}$. The variance in efficacy depends primarily on lamp size (wattage) and color characteristics with the lower wattages exhibiting the lower efficacies. In both of these cases the effect on lamp choice and energy 
savings is expected to be small because at a level of $100 \mathrm{~W}$ and above, lamps with efficacies below 60 $\mathrm{lm} / \mathrm{W}$ are either not available or not commonly used.

To provide some perspective on the potential magnitude of any effect of this requirement we can look at the contribution of exterior lighting to whole building energy use. According to a recent national lighting study (Navigant Consulting 2002) the contribution of HID lighting to various building types is on the order of $10 \%$ to $15 \%$ of total lighting. While some HID is used in the interior and some other non-HID source used for exterior applications, this does provide a reasonable estimate of the magnitude of exterior lighting. It is also generally known that lighting accounts for approximately $30 \%$ of whole building energy use. The combination of these factors produces a potential for exterior energy use of approximately $5 \%$ of whole building energy use. The fraction of $100 \mathrm{~W}$ MV and HPS lamps that would fall under the $60 \mathrm{~lm} / \mathrm{W}$ will be relatively small and therefore likely affecting perhaps less than $1 \%$ of whole building energy use. 


\subsection{References}

Energy Information Administration (EIA). 1999. Commercial Building Energy Consumption and Expenditures Survey 1999 (CBECS 99), U.S. Department of Energy. Washington D.C.

Energy Information Administration (EIA). 2004. Electric Power Monthly, June 2004, EIA website: http://tonto.eia.doe.gov/FTPROOT/electricity/epm/02260406.pdf, U.S. Department of Energy.

Washington D.C.

Navigant Consulting, Inc. 2002. U.S. Lighting Market Characterization, Vol. I: National Lighting Inventory and Energy Consumption Estimates. Navigant Consulting, Inc., Washington D.C.

R.S. Means. 2005. RS Means Electrical Cost Data $28^{\text {th }}$ Annual Edition 2005. R.S. Means, Kingston, Massachusetts.

W.W. Grainger. 2004-2005. Grainger 2004-2005 Catalog No. 395. W.W. Grainger, Lake Forest, Illinois. 


\section{Appendix: Lighting Impacts on Space Conditioning}

Reductions in lighting energy requirements in the proposed code amendments will also lead to secondary impacts on heating and cooling in new commercial buildings. The major impact is to reduce cooling loads and consumption, but during a portion of the year heating consumption can be expected increase.

In recent analyses to consider impact of updated building codes for particular states, PNNL has conducted building simulations upon a limited set of prototypical commercial buildings (office, store, and school). Most of these studies have considered updated codes that include changes to both envelope and lighting requirements. As such, the simulations were conducted to analyze the separate impacts of these types of changes (envelope and lighting) as well as their combined effect.

The current analysis has been restricted to consider only lighting. Given this more narrow focus and the short time requirements for the analysis, this study employs a set of interaction coefficients to estimate the attendant changes in cooling and heating from the reduced lighting consumption. These coefficients pertain to annual energy consumption and are defined on a consistent energy units basis (kWh or Btu). For cooling, we define

Cooling interaction coefficient $=\Delta$ cooling energy use $/ \Delta$ lighting energy use

For heating, interaction coefficient is analogous:

Heating interaction coefficient $=\Delta$ heating energy use $/ \Delta$ lighting energy use

The net change in a building's heating and cooling consumption depends upon a variety of factors, including the building's physical characteristics, operating conditions, climate, and equipment efficiencies. Because these factors vary significantly across buildings, the results presented below can be considered only suggestive of what might be average effects for the population of newly constructed buildings. We need to make clear at the outset that these interaction coefficients are defined in terms of energy consumption and not building loads. Thus, during the cooling season, a reduction of one Btu of internal heat gain from reduced lighting levels may show up as a reduction in the cooling load of nearly one Btu, but typically a much smaller reduction in actual cooling energy use. Most modern commercial cooling equipment uses one-third Btu or less to remove one Btu of heat from the building space. The situation is somewhat different with regard to heating. For gas heating equipment, with combustion efficiencies near $80 \%$, it may require approximately 1.25 Btu of gas consumption to make up for the loss of a Btu provided by the lighting equipment.

The interaction coefficient for cooling also includes any changes in the fan energy (electricity) associated with reduction in the internal heat gain associated with the lower LPDs. The change in fan energy use is a net value - the decrease in fan energy use associated with cooling is offset to some degree by an increase during heating periods. The results shown below suggest that, in Texas, any offsetting increase in fan energy from increased heating use is likely to be small. 
This study follows a two-stage approach to developing the interaction coefficients. For offices, retail, and school, building simulations were conducted for the Dallas and Houston climates. These simulations were conducted using the Buildings Loads Analysis and System Thermodynamics (BLAST) program, developed by the Buildings Systems Laboratory of the University of Illinois. The second stage addressed the other building types. For these building types, a combination of professional judgment and prior simulation studies was employed.

\section{BLAST Simulation Results}

The BLAST simulations were conducted for seven buildings. Four different types of office buildings are characterized to capture the variation in the standard's impacts that stem from alternative-to-wall ratios, building size, and number of floors. One retail prototype was included to represent a "big box" retail building, typical of a large portion of new retail construction. Two schools were simulated, representing a one-story elementary school and a two-story secondary school. The detailed simulation inputs of these buildings are not presented here but can be obtained from any of the recent state-level analyses that are currently posted on the Department of Energy website:

http://www.energycodes.gov/implement/tech_assist_reports.stm.

For the Texas analysis, the key envelope characteristics (wall U-factor, roof U-factor, window U-factor, and window SHGC) were modified to match the requirements for the 2001 IECC (chapter 8). Only the lighting requirements were changed between the two cases that were simulated.

The calculated interaction coefficients for the Texas simulations are shown in Table A.1. The cooling coefficients range between 0.2 and 0.3 , with the coefficients somewhat higher in the hotter Houston climate. The large office has been simulated with an economizer, bringing in outside cooler air when conditions warrant. This feature is largely responsible for the coefficients being lower in the large office as compared to the small office. This impact is not as pronounced in Houston, where the daily minimum temperature is nearly 2.5 degrees F. higher than in Dallas and where typically it is more humid.

The heating systems in the simulations were all assumed to be packaged systems with gas-fired heating. With the exception of the school, the interaction coefficients for heating are relatively small, ranging between 0.2 and 0.10 . With larger ratios of walls to floor area, higher ventilation rates, and smaller assumed internal gains, the base heating consumption in the schools is higher than the other building types. This contributes to the substantially higher heating interaction coefficients for this building type.

Table A.1 Interaction Coefficients based upon BLAST Simulations 


\begin{tabular}{|c|c|c|c|c|c|c|c|}
\hline \multirow[b]{3}{*}{ Building Type } & \multirow[b]{3}{*}{$\begin{array}{l}\text { Size } \\
\text { (sq. ft) }\end{array}$} & \multirow[b]{3}{*}{$\begin{array}{l}\text { No. of } \\
\text { Floors }\end{array}$} & \multirow[b]{3}{*}{$\begin{array}{l}\text { Window-to- } \\
\text { wall ratio }\end{array}$} & \multicolumn{4}{|c|}{ Interaction Coefficients* } \\
\hline & & & & \multicolumn{2}{|c|}{ Dallas } & \multicolumn{2}{|c|}{ Houston } \\
\hline & & & & Cooling & $\begin{array}{l}\text { Heating } \\
\text { (nat.gas) }\end{array}$ & Cooling & $\begin{array}{c}\text { Heating } \\
\text { (nat.gas) }\end{array}$ \\
\hline Small Office & 10,000 & 1 & 0.18 & 0.27 & -0.09 & 0.29 & -0.05 \\
\hline Small Office & 10,000 & 1 & 0.38 & 0.27 & -0.10 & 0.28 & -0.06 \\
\hline Large Office & 60,000 & 3 & 0.18 & 0.23 & -0.07 & 0.27 & -0.04 \\
\hline Large Office & 60,000 & 3 & 0.38 & 0.23 & -0.07 & 0.27 & -0.05 \\
\hline Retail & 24,000 & 1 & 0.07 & 0.27 & -0.07 & 0.28 & -0.02 \\
\hline Education & 50,000 & 1 & 0.18 & 0.27 & -0.24 & 0.30 & -0.17 \\
\hline Education & 80,000 & 2 & 0.18 & 0.28 & -0.22 & 0.30 & -0.15 \\
\hline
\end{tabular}

${ }^{*}$ Change (MMBtu) in annual cooling or heating consumption per MMBtu of lighting reduction

\section{Interaction Coefficients for All Building Types}

While office, retail, and education buildings account for nearly half of the new floor space in new construction, that still leaves a sizable percentage of floor space in variety of other building types. Estimation of approximate interaction coefficients for these building was based upon PNNL analyst judgment and a 1998 study conducted by Lawrence Berkeley National Laboratory (LBNL). ${ }^{10}$ The 1998 LBNL study conducted a broad series of simulations across a variety of climate locations in the U.S. and for eleven building types. Table $1 \mathrm{~b}$ in the LBNL report presents a set of interaction coefficients for heating and cooling, aggregated to a national basis.

Table A.2 shows the interaction coefficients used in the current analysis. For office, retail, and schools, the coefficients are an approximate average of the coefficients shown in Table A.1. As discussed in the LBNL study, the cooling interaction coefficients are generally greater in larger buildings. This result is consistent with a higher percentage of the floor area in these buildings that in the building core, and as such, cooling is required all or nearly all the year. The LBNL results relate only to national averages. However, the Texas climate is considerably warmer than the U.S. average and thus, in many building types, cooling is required in the perimeter zones of many building for a large portion of the year.

According we have generally set the cooling coefficients between 0.2 and 0.3 in most of the building types. Notable exceptions are manufacturing buildings, warehouses, parking garages, and automotive repair, where mechanical cooling is not likely to be prevalent.

\footnotetext{
${ }^{10}$ Interactions between Lighting and Space Conditioning Energy Use in U.S. Commercial Buildings. LBNL-39795. Osman Sezgen and Jonathan Koomey. Energy Analysis Department, Lawrence Berkeley National Laboratory. April 1998.
} 
Table A.2 Interaction Coefficients Used in Current Study

\begin{tabular}{|c|c|c|}
\hline Building Type & $\begin{array}{l}\text { Cooling } \\
\text { (elec.) }\end{array}$ & $\begin{array}{c}\text { Heating } \\
\text { (nat. gas) }\end{array}$ \\
\hline Automotive Repair & 0.02 & -0.02 \\
\hline Convention Center & 0.25 & -0.07 \\
\hline Courthouse & 0.25 & -0.07 \\
\hline Dining-Bar Lounge/Leisure & 0.30 & -0.05 \\
\hline Dining-Café/Fast Food & 0.30 & -0.05 \\
\hline Dining-Family & 0.30 & -0.05 \\
\hline Dormitory & 0.25 & -0.15 \\
\hline Exercise Center & 0.30 & -0.07 \\
\hline Fire Station & 0.20 & -0.05 \\
\hline Gymnasium & 0.20 & -0.05 \\
\hline Healthcare-Hospital & 0.30 & -0.05 \\
\hline Hotel & 0.25 & -0.15 \\
\hline Library & 0.25 & -0.07 \\
\hline Manufacturing & 0.10 & -0.05 \\
\hline Motel & 0.25 & -0.15 \\
\hline Multi-Family & 0.30 & -0.10 \\
\hline Museum & 0.30 & -0.07 \\
\hline Office & 0.28 & -0.07 \\
\hline Parking Garage & 0.00 & 0.00 \\
\hline Penitentiary & 0.30 & -0.10 \\
\hline Police Station & 0.25 & -0.07 \\
\hline Post Office & 0.25 & -0.07 \\
\hline Religious & 0.20 & -0.10 \\
\hline Retail & 0.28 & -0.05 \\
\hline School-College & 0.25 & -0.20 \\
\hline Sports Arena & 0.25 & -0.07 \\
\hline Theater-Performing Arts & 0.25 & -0.07 \\
\hline Theatre-Motion Picture & 0.25 & -0.07 \\
\hline Town Hall & 0.25 & -0.07 \\
\hline Transportation & 0.25 & -0.07 \\
\hline Warehouse & 0.05 & -0.02 \\
\hline Workshop & 0.10 & -0.05 \\
\hline
\end{tabular}

